\title{
Studies on Seed Germination, Seedling Growth, and In Vitro Shoot Induction of Aloe ferox Mill., a Commercially Important Species
}

\author{
Michael W. Bairu, Manoj G. Kulkarni, Renée A. Street, Rofhiwa \\ B. Mulaudzi, and Johannes Van Staden ${ }^{1}$ \\ Research Centre for Plant Growth and Development, School of Biological \\ and Conservation Sciences, University of KwaZulu-Natal Pietermaritzburg, \\ Private Bag X01, Scottsville 3209, South Africa
}

Additional index words. cytokinins, growth regulators, multiplication rate, smoke solutions, temperature, tissue culture

\begin{abstract}
A study was done to investigate the effects of some physical and chemical factors on growth and development of Aloe ferox ex vitro and in vitro. The effects of light, temperature, and smoke-water on seed germination, ex vitro seedling growth requirements, and effect of germination medium and cytokinins on shoot induction and multiplication in vitro were investigated. The highest germination percentage of $A$. ferox seeds was recorded between 15 and $30{ }^{\circ} \mathrm{C}$. Seed germination was inhibited at 10 and $35{ }^{\circ} \mathrm{C}$. There was a nonsignificant increase in germination percentage $(78 \%)$ for seeds that were germinated under constant dark conditions. Smoke-water-treated seeds showed significant improvement in percentage germination $(80 \%)$ over the control $(66 \%)$ at $25^{\circ} \mathrm{C}$ with a 16 -h photoperiod. Seedlings of $A$. ferox subjected to alternating temperatures $\left(30 / 15^{\circ} \mathrm{C}\right)$ or being irrigated three times weekly at $25{ }^{\circ} \mathrm{C}$ showed better seedling growth. In an in vitro experiment, seedlings germinated in distilled water and one-tenth strength Murashige and Skoog medium had superior shoot induction competence compared with the other germination media. The cytokinins meta-Topolin $(m \mathrm{~T})$ and meta-Topolin riboside $(m \mathrm{TR})$ at $5 \mu \mathrm{M}$ gave significantly higher shoot multiplication rates compared with the control and benzyladenine (BA)-treated plants. A higher abnormality index was recorded for BA-treated plants. The findings of this study will be beneficial for commercial propagation of Aloe ferox.
\end{abstract}

Aloes grow in a wide range of habitats and are an important group of medicinal plants in Africa. Traditionally, the harvesting of plant parts was sustainable and limited to household use. Currently, many Aloe species are threatened in Africa as a result of commercial use (Maundu et al., 2004). Pfab and Scholes (2004) reported that harvesting only one adult plant annually from a population of 100 Aloe peglerae produces an extinction probability of $100 \%$. This means harvesting of only $0.12 \%$ or less of the mature plants of A. peglerae per year can be considered as sustainable. Aloe ferox is another widely harvested South African species (Sachedina and Bodeker, 1999). The bitter yellow juice and gel obtained from the leaves of this species are used as a laxative and for healthcare products, respectively (Van Wyk et al., 1997). Newton and Vaughan (1996) estimated that in 1990, A. ferox leaves were

\footnotetext{
Received for publication 11 Dec. 2008. Accepted for publication 25 Mar. 2009.

The National Research Foundation (NRF), Pretoria, and the University of KwaZulu-Natal are thanked for financial support.

${ }^{1}$ To whom reprint requests should be addressed; e-mail rcpgd@ukzn.ac.za.
}

officially harvested from $\approx 10$ million plants for $400 \mathrm{t}$ of bitters. They also reported that there was an unofficial trade of another $300 \mathrm{t}$ of bitters, suggesting a need for the safeguarding of this species. The export details of A. ferox extract from South Africa between 1994 and 2003 is documented by Knapp (2006). Overall, the value of the A. ferox industry in South Africa is estimated to be R150 million (U.S. \$15 million) per year. Government and private sectors are expanding this industry for the benefits of rural communities as a result of the increasing demand for A. ferox bitters and gel (Shackleton and Gambiza, 2007).

At present, A. ferox is not vulnerable in the wild. However, there is concern that overharvesting of leaves, although this does not harm the plant, may affect growth, flowering, and make the plant less resistant to drought (Donaldson, 1989; Newton and Vaughan, 1996), which can lead to local extinction (Van Wyk and Smith, 1996). Pfab and Scholes (2004) emphasized that sustainability can never be achieved without ex situ cultivation.

Tree and shrub species of Aloes are propagated through stem cuttings, which are dried and planted. A more or less similar method is adopted for suckering species in which small plantlets are detached from the mother plant that are dried and planted. However, seed propagation is more feasible and recommended for survival of rare species (Van Wyk and Smith, 1996). If this species has to be propagated on a large scale by means of seed or tissue culture methods, then currently there is no basic information available on these aspects. Aloes are succulent and warm-climate plants, where both temperature and water play an important role in establishing them. This study was therefore conducted to examine 1) the effects of different temperatures, growth-promoting substances, and watering frequencies on seed germination and seedling growth of $A$. ferox; and 2) to assess the applicability of an in vitro propagation protocol developed for other Aloe spp.

\section{Materials and Methods}

Seed collection. Dried seeds of A. ferox were collected between the middle to the end of August from the Botanical Garden, University of KwaZulu-Natal Pietermaritzburg, South Africa. Seeds of $A$. ferox are black in color, triangular in shape with a size ranging between 0.3 and $0.5 \mathrm{~mm}$. The average weight of 100 seeds determined was $174 \pm 4 \mathrm{mg}$ with $8 \%$ moisture content at harvest. Collected seeds were used immediately.

Seed germination experiments. To determine the optimum requirements for seed germination of $A$. ferox, the seeds were subjected to different temperature regimes, light conditions, plant growth regulators (PGRs), potassium nitrate, and smoke solutions. Seeds were decontaminated with $0.1 \%$ mercuric chloride for $1 \mathrm{~min}$ and then rinsed with distilled water before germination tests. All treatments consisted of four replicates with 25 seeds in each. The seeds were placed on two layers of Whatman No. 1 filter paper in disposable plastic petri dishes $(9 \mathrm{~cm})$. The filter paper was wetted with $4 \mathrm{~mL}$ distilled water, PGRs, potassium nitrate, or smoke solutions and kept moist by adding aliquots of the respective solutions when required until the end of the experiment. Plant growth regulators used in this experiment were gibberellic acid $\left(\mathrm{GA}_{3}\right)$ and kinetin (Sigma Chemical Co., St. Louis, MO) at concentrations of $10^{-3}, 10^{-4}$, and $10^{-5} \mathrm{M}\left(\mathrm{GA}_{3} 346.4\right.$, 34.64 , and $3.464 \mathrm{mg} \cdot \mathrm{L}^{-1}$, respectively; kinetin $215.2,21.52$, and $2.152 \mathrm{mg} \cdot \mathrm{L}^{-1}$ respectively). Potassium nitrate $\left(\mathrm{KNO}_{3}\right)$ (Merck, Darmstadt, Germany) was tested at $10^{-3}, 10^{-4}$, and $10^{-5} \mathrm{M}\left(101.10,10.10\right.$, and $1.010 \mathrm{mg} \cdot \mathrm{L}^{-1}$, respectively). Seeds were incubated with smoke-water (smoke concentrate and water dilution of 1:500 v/v) or an active compound butenolide [3-methyl-2 $H$-furo(2,3-c)pyran2-one] $\left(10^{-8} \mathrm{M}\right)$ isolated from smoke. The smoke-water was prepared by the methods outlined in Baxter et al. (1994), and the butenolide was isolated from plant-derived smoke-water according to the methods described by Van Staden et al. (2004). To determine the effects of different temperatures, the seeds were incubated at 10, 15, 20, 25, 30,35 , and $30 / 15^{\circ} \mathrm{C}$. The experiments were 
conducted under a 16-h photoperiod with cool-white fluorescent lamps, which provided a photosynthetic photon flux density $(P P F D)$ of $75.6 \pm 3.8 \mu \mathrm{mol} \cdot \mathrm{m}^{-2} \cdot \mathrm{s}^{-1}$. For continuous dark conditions, the petri dishes were placed in light proof boxes at $25 \pm 0.5$ ${ }^{\circ} \mathrm{C}$, and the seeds were inspected daily under green "safe light" conditions with a PPFD of $0.3 \mu \mathrm{mol} \cdot \mathrm{m}^{-2} \cdot \mathrm{s}^{-1}$. In continuous light conditions, the $P P F D$ was $76.4 \pm 3.5 \mu \mathrm{mol} \cdot \mathrm{m}^{-2} \cdot \mathrm{s}^{-1}$ at $25^{\circ} \mathrm{C}$.

Germination was recorded daily and was considered complete once the radicle protruded $\approx 2 \mathrm{~mm}$ in length. The experiments were continued for $14 \mathrm{~d}$. Mean germination time (MGT) was calculated by using the equation: $\mathrm{MGT}=\sum(\mathrm{n} \times \mathrm{d}) / \mathrm{N}$, where $\mathrm{n}=$ number of seeds germinated on each day, $d=$ number of days from the beginning of the test, and $\mathrm{N}=$ total number of seeds germinated at the termination of the experiment (Ellis and Roberts, 1981). The optimum temperature for germination was calculated on the basis of constant temperature as: $\mathrm{To}_{\mathrm{o}}=$ $\sum \mathrm{tp} / \sum \mathrm{p}$, where $\mathrm{p}$ is the percentage germination at temperature t (Olff et al., 1994).

Seedling growth experiments. Two-weekold seedlings grown in petri dishes were transplanted into $20-\mathrm{cm}$ pots filled with sterile quartz sand (sulfuric acid-washed, thorough rinsing with water cycles, and dried in an oven at $80{ }^{\circ} \mathrm{C}$ for $7 \mathrm{~d}$ ) and moistened $(1.3 \mathrm{~kg})$ with half-strength Hoagland's nutrient solution (HS) $(75 \mathrm{~mL}$ ) (Hoagland and Snyder, 1933). Each pot consisted of five seedlings with eight replications per treatment. The pots were arranged randomly in the plant growth chambers under a 16-h photoperiod with a $P P F D$ of $80.4 \pm 3.5$ $\mu \mathrm{mol} \cdot \mathrm{m}^{-2} \cdot \mathrm{s}^{-1}$ at $25^{\circ} \mathrm{C}$.

To test the effects of different temperatures on seedling growth, the pots were placed at constant $\left(10,15,20,25,30,35^{\circ} \mathrm{C}\right)$ and alternating $\left(30 / 15{ }^{\circ} \mathrm{C}\right)$ temperatures. Once weekly, $75 \mathrm{~mL}$ half-strength HS was added to each pot. The potting sand was kept moist with water when required. The seedlings were harvested after 12 weeks and various growth parameters were recorded for statistical analysis.

In this study, three levels of watering frequencies (W1, watering once; W2, watering twice; and W3, watering three times weekly) were tested at $25^{\circ} \mathrm{C}$ by adding $75 \mathrm{~mL}$ of water. One weekly watering was replaced by adding $75 \mathrm{~mL}$ half-strength $(50 \%) \mathrm{HS}$. The experiment was continued for 12 weeks and various growth parameters of harvested seedlings were recorded and analyzed.

In vitro seed germination and shoot induction. Some of the seeds collected from the University of KwaZulu-Natal Botanical Gardens were immediately used for in vitro germination tests. Six different types of germination media, namely distilled water, distilled water $+1 \%$ sucrose $+0.1 \mathrm{~g} \cdot \mathrm{L}^{-1}$ myoinositol, one-tenth strength Murashige and Skoog (MS), one-fourth strength MS, halfstrength MS, and full-strength MS, were tested. After data on in vitro germination were collected, germinated seedlings were tested for their shoot multiplication potential using the protocol developed by Bairu et al. (2007). This protocol involves the use of fullstrength MS medium (Murashige and Skoog, 1962) supplemented with $30 \mathrm{~g} \cdot \mathrm{L}^{-1}$ sucrose, $0.1 \mathrm{~g} \cdot \mathrm{L}^{-1}$ myo-inositol (Sigma Chemical Co.), $2.45 \mu \mathrm{M}$ indolebutyric acid (Sigma Chemical Co.), $5 \mu \mathrm{M}$ meta-Topolin (Laboratory of Growth Regulators, Olomouc, Czech Republic), and solidified with 1\% agar (Bacteriological agar-Oxoid Ltd., Basingstoke, Hampshire, U.K.). The media were autoclaved for $20 \mathrm{~min}$ at $121{ }^{\circ} \mathrm{C}$ and $103 \mathrm{kPa}$ after the $\mathrm{pH}$ was adjusted to 5.8. Fifty milliliters of the medium was then poured into each of the autoclaved screw-cap jars. Shoottip cultures were incubated in a growth room with continuous cool fluorescent tubes (Osram $\mathrm{L} 75 \mathrm{~W} / 20 \mathrm{X})$ light intensity of $45 \mu \mathrm{mol} \cdot \mathrm{m}^{-2} \cdot \mathrm{s}^{-1}$ and a temperature of $24 \pm 1{ }^{\circ} \mathrm{C}$ for 9 weeks. The data on shoot multiplication, shoot length, and rooting were collected and analyzed after 9 weeks of growth in culture.

Shoot multiplication. After bulking sufficient explants using the previously described procedure, experiments to investigate the effects of type and concentration of cytokinin on shoot multiplication and incidence of abnormality were designed. Benzyladenine and the meta-topolins, $m \mathrm{~T}$ and $m \mathrm{TR}$, were investigated at 2.5 and $5.0 \mu \mathrm{m}$ concentrations. Five shoot-tip ( $2 \mathrm{~cm}$ each) explants (derived from seedlings germinated in one-tenth strength MS and agar) with two to three young leaves attached were cultured in screw-cap jars $(300 \mathrm{~mL})$ containing $50 \mathrm{~mL}$ of media. A total of 15 explants per treatment was used. Cultures were then incubated under the same growth conditions mentioned previously. Growth parameters such as multiplication rate (total number of shoots per jar divided by initial number of explants) and abnormality index (the ratio of abnormal to normal shoots) were calculated and analyzed after 9 weeks. Plantlets exhibiting undifferentiated growth, hyperhydricity, and deformity were considered abnormal.

Statistical analysis. Ex vitro results were analyzed using MINITAB ${ }^{\circledR}$ release 14 statistical package (Minitab Inc., State College, PA). One-way analysis of variance was conducted to test Fisher's significance level at $5 \%$. Percentage germination data were arcsine transformed before analysis. Data from the tissue culture experiments were analyzed using SPSS $^{\circledR}$ release 10 statistical package (SPSS Inc., Chicago, IL) at 5\% probability levels. Mean separation for significance test was made using the Duncan's multiple range test. Kruskal-Wallis test was conducted using the MINITAB ${ }^{\circledR}$ package to analyze nonparametric data.

\section{Results}

Effect of temperatures, light conditions, plant growth regulators, $\mathrm{KNO}_{3}$, and smoke solutions on seed germination. Seeds of $A$. ferox incubated at $30{ }^{\circ} \mathrm{C}$ showed the highest percentage germination $(76 \%)$ in comparison with the other temperatures (Fig. 1A). On the other hand, $35^{\circ} \mathrm{C}$ had significantly lower germination $(10 \%)$. Alternating temperatures $\left(30 / 15{ }^{\circ} \mathrm{C}\right)$ showed an intermediate response to percentage germination (Fig. 1A). Different light conditions had no significant effect on the percentage germination. However, greater percentage germination $(78 \%)$ was recorded under constant dark than with the seeds that were exposed to constant and alternating light conditions (Fig. 1B). Smokewater $(1: 500 \mathrm{v} / \mathrm{v})$ significantly increased percentage germination over the control seeds (Fig. 2). The different PGRs and $\mathrm{KNO}_{3}$ solutions tested in this study did not significantly affect germination.

Effect of temperatures and watering frequencies on seedling growth. The longest

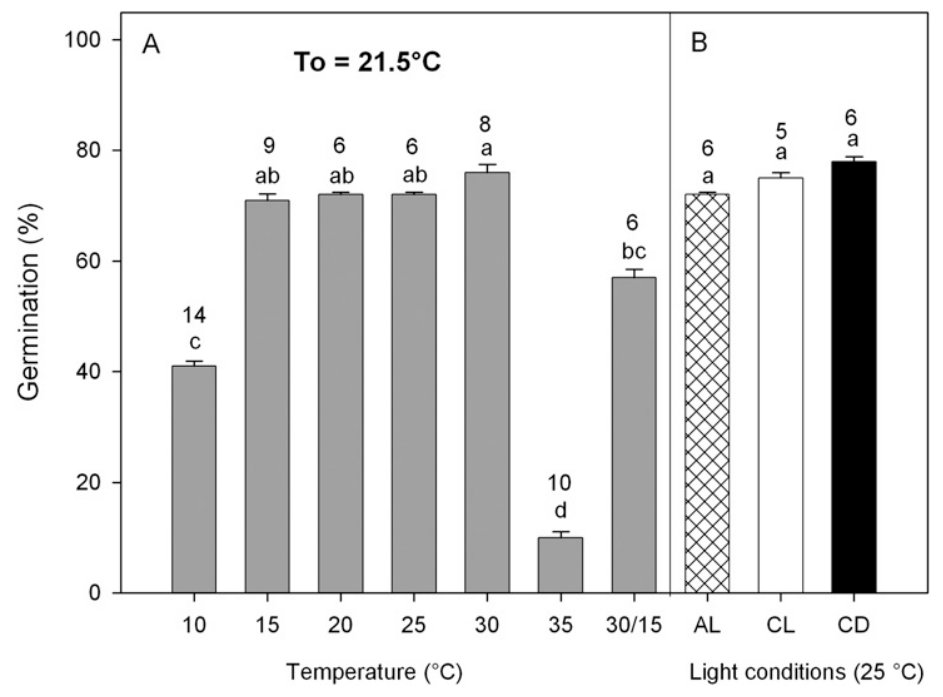

Fig. 1. (A) Effect of different temperature (16-h photoperiod) and (B) light conditions (AL = alternating light; $\mathrm{CL}=$ constant light; $\mathrm{CD}=$ constant dark) on percentage seed germination of Aloe ferox. SE bars with different letter(s) are significantly different $(P<0.05)$ by Fisher's test. Numbers above the letter(s) indicate mean germination time in days. To $=$ calculated optimum temperature. 


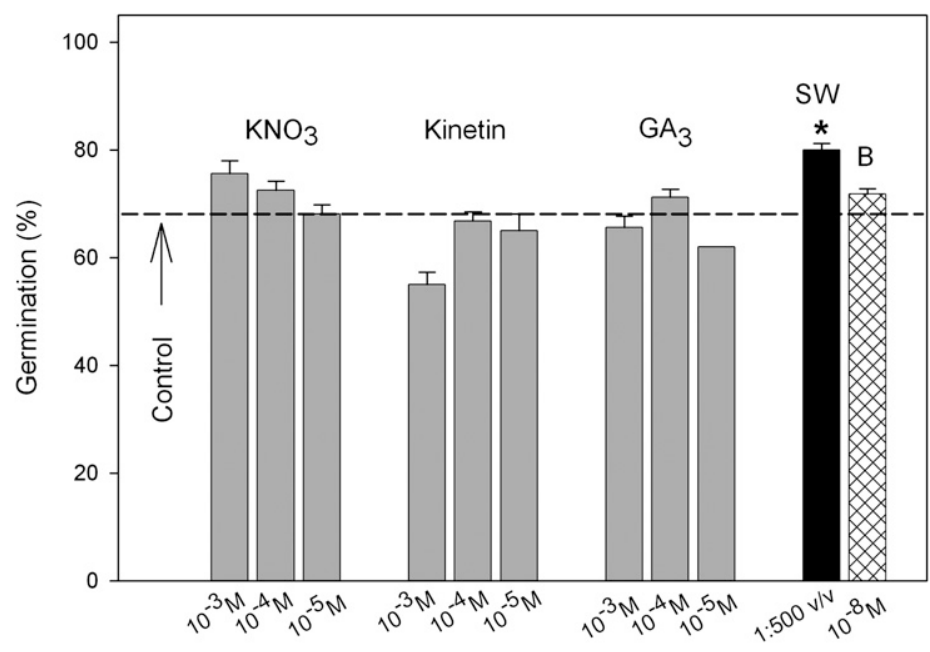

Concentrations

Fig. 2. Effect of different concentrations of plant growth regulators [gibberellic acid $\left(\mathrm{GA}_{3}\right)$ and kinetin], potassium nitrate $\left(\mathrm{KNO}_{3}\right)$, and smoke solutions $(\mathrm{SW}=$ smoke-water; $\mathrm{B}=$ butenolide $)$ on percentage seed germination of Aloe ferox at $25{ }^{\circ} \mathrm{C}$ with a 16-h photoperiod. Asterisk indicates significant difference from the control at $5 \%$ level $(P<0.05)$ by Fisher's test. Mean germination time was $8 \mathrm{~d}$ for all treatments.

Table 1. Effect of different temperatures on seedling growth of Aloe ferox under a 16-h photoperiod.

\begin{tabular}{llcccc}
\hline $\begin{array}{l}\text { Temperature } \\
\left({ }^{\circ} \mathrm{C}\right)\end{array}$ & $\begin{array}{c}\text { Shoot length } \\
(\mathrm{mm})\end{array}$ & $\begin{array}{c}\text { Root length } \\
(\mathrm{mm})\end{array}$ & \multicolumn{1}{c}{ Leaf $($ no. $)$} & Root $($ no. $)$ & $\begin{array}{c}\text { Seedling fresh } \\
\text { wt }(\mathrm{g})\end{array}$ \\
\hline 10 & $17 \pm 0.46 \mathrm{~d}^{\mathrm{z}}$ & $7 \pm 0.19 \mathrm{e}$ & $1.61 \pm 0.04 \mathrm{~d}$ & $0 \mathrm{~d}$ & $0.259 \pm 0.020 \mathrm{~cd}$ \\
15 & $25 \pm 0.59 \mathrm{~d}$ & $14 \pm 1.54 \mathrm{de}$ & $2.30 \pm 0.13 \mathrm{c}$ & $3.5 \pm 0.33 \mathrm{c}$ & $0.445 \pm 0.021 \mathrm{~d}$ \\
20 & $22 \pm 0.64 \mathrm{~d}$ & $25 \pm 1.99 \mathrm{c}$ & $2.50 \pm 0.10 \mathrm{c}$ & $5.0 \pm 0.41 \mathrm{ab}$ & $0.663 \pm 0.038 \mathrm{~cd}$ \\
25 & $50 \pm 3.17 \mathrm{c}$ & $61 \pm 2.47 \mathrm{ab}$ & $3.60 \pm 0.17 \mathrm{ab}$ & $5.8 \pm 0.39 \mathrm{a}$ & $1.550 \pm 0.159 \mathrm{~b}$ \\
30 & $61 \pm 3.41 \mathrm{ab}$ & $53 \pm 3.30 \mathrm{~b}$ & $3.80 \pm 0.18 \mathrm{ab}$ & $6.4 \pm 0.49 \mathrm{a}$ & $2.341 \pm 0.231 \mathrm{a}$ \\
35 & $57 \pm 4.13 \mathrm{bc}$ & $19 \pm 2.47 \mathrm{~cd}$ & $3.23 \pm 0.21 \mathrm{~b}$ & $5.4 \pm 0.29 \mathrm{ab}$ & $0.858 \pm 0.145 \mathrm{c}$ \\
$30 / 15$ & $67 \pm 2.02 \mathrm{a}$ & $64 \pm 3.90 \mathrm{a}$ & $3.95 \pm 0.05 \mathrm{a}$ & $4.2 \pm 0.22 \mathrm{bc}$ & $1.973 \pm 0.153 \mathrm{ab}$ \\
\hline
\end{tabular}

${ }^{2}$ Mean value and SE $( \pm)$ in the column with different letter(s) are significantly different $(P<0.05)$ by Fisher's test.

shoots were recorded at alternating temperatures $\left(30 / 15{ }^{\circ} \mathrm{C}\right)$, which was significantly different from other temperatures with the exception of $30^{\circ} \mathrm{C}$ (Table 1). The root length also significantly increased at $30 / 15^{\circ} \mathrm{C}$ with the exception of $25^{\circ} \mathrm{C}$. Maximum number of leaves was recorded at $30 / 15^{\circ} \mathrm{C}$, whereas a greater number of roots were developed at $30{ }^{\circ} \mathrm{C}$. The seedlings that were grown at 30 ${ }^{\circ} \mathrm{C}$ showed significantly greater fresh weight than at the other temperatures with the exception of $30 / 15^{\circ} \mathrm{C}$ (Table 1$)$. Watering frequencies of twice and three times weekly (W2 and W3) showed significantly longer root lengths (69 and $72 \mathrm{~mm}$, respectively) than once weekly watering (W1) (51 mm) (Fig. 3). Although, in these watering frequencies, there was an increase in the length of shoots, these results were not significantly different from the seedlings that were watered once weekly. Watering of seedlings three times weekly had significantly more roots than watering once weekly. Seedling fresh weight was significantly greater for W2 and W3 treatments than W1 (Fig. 3).

In vitro seed germination and shoot induction. In vitro seed germination of $A$. ferox was very erratic. Seeds started germinating on Day 10 and continued to germinate for more than 1 month. Seeds germinated on all the different germination media tested. There was, however, a difference in the quality of seedlings produced and their subsequent response to in vitro culture treatments. Seeds germinated in distilled water and agar and one-tenth strength MS solid media showed better in vitro multiplication (Fig. 4). The different germination media also had a significant effect on shoot growth as indicated by shoot length (Fig. 5). These different germination media, however, did not have significant effects on rooting when transferred to shoot induction medium as revealed by the Kruskal-Wallis test on rooting scores (data not presented).

Seedlings germinated in one-tenth strength MS media were used for the multiplication experiment as a result of their superior response to in vitro treatment. Subculturing plants to fresh multiplication medium significantly improved shoot multiplication. This was evident when we compare the $12.0 \pm 1.4$ shoots per explant obtained from the $5 \mu \mathrm{M} m \mathrm{~T}$ treatment (Table 2) with the $4.57 \pm 0.9$ (Fig. 4) on the same treatment during the shoot induction phase. The $m \mathrm{TR}$ at $5 \mu \mathrm{M}$ gave the highest multiplication rate, which was significantly higher than benzyla-

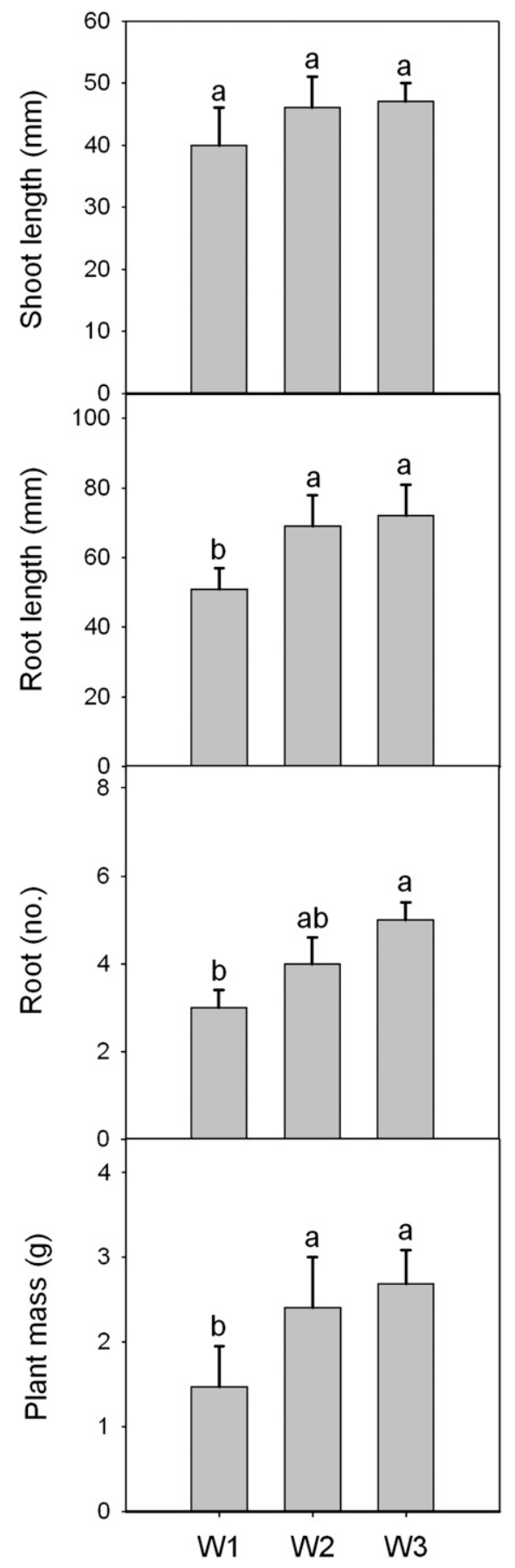

Watering frequencies (weekly)

Fig. 3. Effect of watering frequencies (W1, once; W2, twice; and W3, three times weekly) on seedling growth of Aloe ferox at $25^{\circ} \mathrm{C}$ under a 16-h photoperiod. SE bars with different letter(s) are significantly different $(P<0.05)$ by Fisher's test.

denine at the same concentration but not significantly different when compared with $m \mathrm{~T}$. Benzyladenine also appears to be more detrimental than the topolins based on the abnormality index.

Plantlets failed to root in a multiplication medium, but rooting was achieved easily by transferring elongated shoots to cytokinin-free 


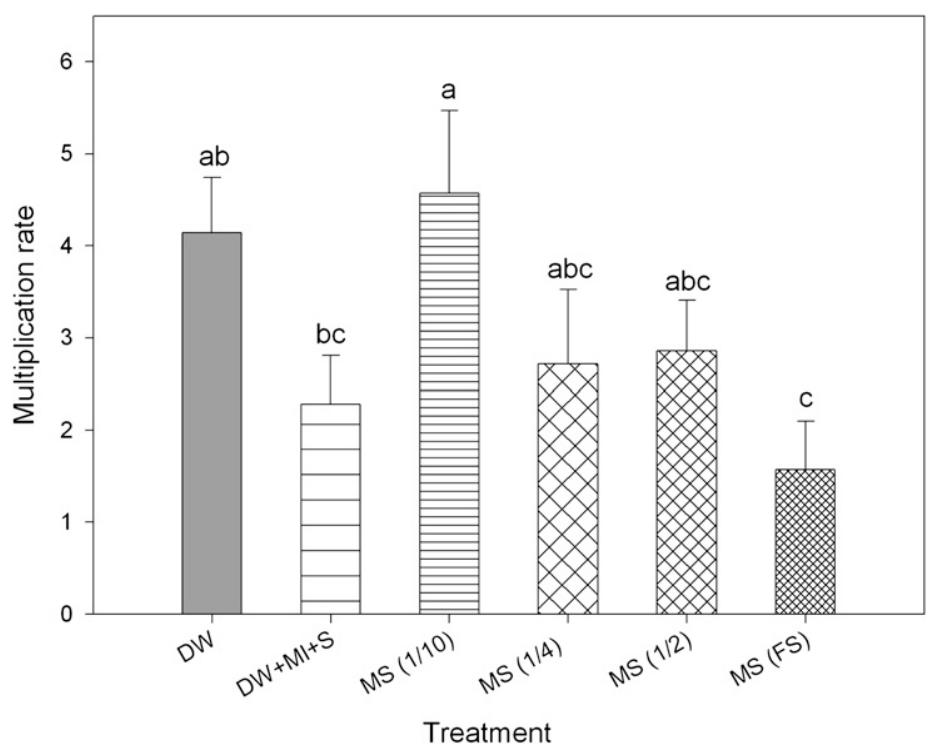

Fig. 4. Effect of in vitro germination medium on shoot induction competence (multiplication rate $=$ total number of shoots per jar divided by initial number of explants) when subcultured to multiplication medium. DW = distilled water; FS = full strength; $\mathrm{MI}=$ myo-inositol; $\mathrm{MS}=$ Murashige and Skoog media; $\mathrm{S}=$ sucrose. SE bars with different letter(s) are significantly different $(P<0.05)$ by Duncan's multiple range test.

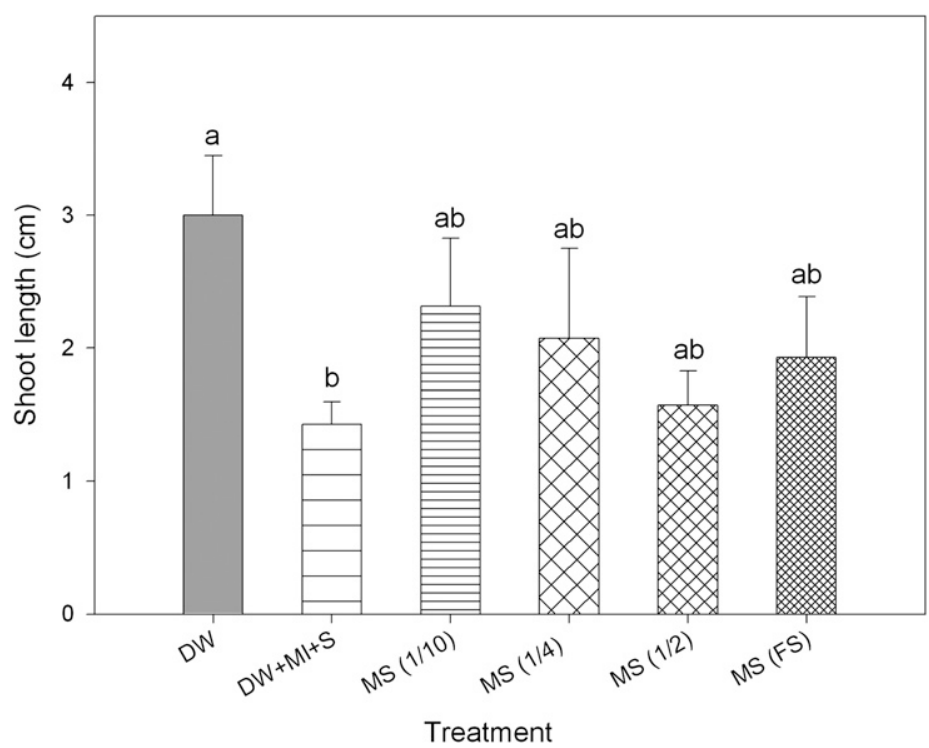

Fig. 5. Effect of in vitro germination medium on shoot length when subcultured to multiplication medium. $\mathrm{DW}=$ distilled water; FS = full strength; $\mathrm{MI}=$ myo-inositol; $\mathrm{MS}=$ Murashige and Skoog media; $\mathrm{S}=$ sucrose. SE bars with different letter(s) are significantly different $(P<0.05)$ by Duncan's multiple range test.

medium as described previously. Furthermore, some browning was observed (Fig. 6A). This problem, however, had little effect on the formation of shoot clusters (Fig. 6B) when cultures were transferred to fresh medium 2 weeks after the initial culture. The severity of the problem was reduced with subsequent subcultures.

\section{Discussion}

Ex vitro seed germination and seedling growth requirements. Temperature and light are two important factors that influence seed germination of a number of species. In this study, the seeds of $A$. ferox showed better percentage germination (greater than 70\%) between 15 and $30^{\circ} \mathrm{C}$ with a lower MGT than at 10 and $35^{\circ} \mathrm{C}$. A broad range of temperature for germination can be attributed to the wide distribution of this species in South Africa (Shackleton and Gambiza, 2007; Van der Bank et al., 1995). Lower $\left(10^{\circ} \mathrm{C}\right)$ and higher $\left(35^{\circ} \mathrm{C}\right)$ temperatures were detrimental for seed germination of $A$. ferox (Fig. 1). Alternating temperatures $\left(30 / 15{ }^{\circ} \mathrm{C}\right)$ were not effective in optimizing germination. Seeds of $A$. ferox incubated at all temperatures did not achieve optimum germination, although the seeds of $A$. ferox showed a viability of $95 \%$ or greater that was determined by the TTC method (International Seed Testing Association, 1999). This can be attributed to the need of an after-ripening period for $A$. ferox seeds to reach full maturity for maximum germination. However, this aspect needs further study. In regard to the effects of temperatures, the maximum percentage germination $(76 \%)$ was obtained at $30{ }^{\circ} \mathrm{C}$ with a 16 -h photoperiod. The best germination $(78 \%)$ was achieved at $25{ }^{\circ} \mathrm{C}$ under constant dark conditions (Fig. 1). Smokewater treatment significantly improved the germination of $A$. ferox seeds at $25^{\circ} \mathrm{C}$ with a $16-\mathrm{h}$ photoperiod. It is apparent that smokewater shows similar effects to PGRs (Kulkarni et al., 2006) and therefore smoke solutions are now widely used to enhance seed germination of many plant species (Light and Van Staden, 2004). The PGRs examined were not as effective as smoke-water.

Temperature has a vital influence on early developmental stages of the seedlings. Aloe ferox seedlings subjected to different temperatures under controlled conditions showed variations in growth. Alternating temperatures $\left(30 / 15^{\circ} \mathrm{C}\right)$ were the best for shoot and root growth and increasing the number of leaves. Subsequently, most of the growth parameters were better at $30{ }^{\circ} \mathrm{C}$ than the other constant temperatures examined (Table 1). Low $\left(10,15\right.$, and $\left.20^{\circ} \mathrm{C}\right)$ and high temperatures $\left(35^{\circ} \mathrm{C}\right)$ suppressed the growth of seedlings, indicating that these temperatures are not suitable for propagation of $A$. ferox. However, in the case of $A$. vera, it is suggested that this species can be considered as a potential crop in regions with low temperatures with negligible losses in gel production (Saks and Ish-shalom-Gordon, 1995). A study by Rodríguez-García et al. (2007), on the same species, showed that low soil water potential reduced leaf weight, plant growth rate, and leaf number, indicating sensitivity of newly developed leaves to water stress. This indicates that watering level in the soils is important for the growth of Aloes. Irrigating seedlings of $A$. ferox once weekly showed a similar response with decline in shoot and root length, number of roots, and fresh weight of seedling. On the other hand, watering of $A$. ferox seedlings three times weekly enhanced most of the growth parameters studied. This result suggests that regular watering frequencies are crucial for growing $A$. ferox seedlings.

In vitro seed germination and shoot multiplication. The unsynchronized in vitro germination of $A$. ferox seeds warrants the need for some pretreatments. Because optimizing the in vitro seed germination of this species was not the main objective of this study, it was set aside for future investigation. Of considerable importance is the role the germination media played on in vitro shoot multiplication potential of the seedlings. Generally, media high in salt and sugar content reduced germination efficacy and subsequent shoot multiplication potential. This 
Table 2. Effect of cytokinin type and concentration on in vitro shoot multiplication and incidence of abnormality in Aloe ferox. ${ }^{\mathrm{y}}$

\begin{tabular}{lcccc}
\hline $\begin{array}{l}\text { Treatment } \\
(\mu \mathrm{M})\end{array}$ & $\begin{array}{c}\text { Shoot/explant } \\
(\text { no. })\end{array}$ & $\begin{array}{c}\text { Normal } \\
\text { shoot/explant (no.) }\end{array}$ & $\begin{array}{c}\text { Abnormal } \\
\text { shoot/explant (no.) }\end{array}$ & $\begin{array}{c}\text { Abnormality } \\
\text { index }\end{array}$ \\
\hline Control & $2.1 \pm 0.4 \mathrm{c}^{\mathrm{y}}$ & $2.1 \pm 0.6 \mathrm{~d}$ & $0 \mathrm{~d}$ & $0 \mathrm{c}$ \\
$2.5 \mathrm{BA}$ & $7.0 \pm 1.5 \mathrm{~b}$ & $4.1 \pm 1.2 \mathrm{c}$ & $2.9 \pm 0.8 \mathrm{~b}$ & $0.71 \pm 0.2 \mathrm{a}$ \\
$2.5 \mathrm{mT}$ & $8.2 \pm 1.7 \mathrm{~b}$ & $6.8 \pm 1.5 \mathrm{bc}$ & $1.4 \pm 0.4 \mathrm{c}$ & $0.21 \pm 0.06 \mathrm{~b}$ \\
$2.5 \mathrm{mTR}$ & $8.5 \pm 1.9 \mathrm{~b}$ & $7.0 \pm 1.6 \mathrm{~b}$ & $1.5 \pm 0.4 \mathrm{c}$ & $0.21 \pm 0.07 \mathrm{~b}$ \\
$5 \mathrm{BA}$ & $10.0 \pm 1.8 \mathrm{ab}$ & $5.1 \pm 1.4 \mathrm{c}$ & $4.9 \pm 1.1 \mathrm{a}$ & $0.96 \pm 0.029 \mathrm{a}$ \\
$5 \mathrm{mT}$ & $12.0 \pm 1.4 \mathrm{a}$ & $10.2 \pm 2.4 \mathrm{a}$ & $1.8 \pm 0.6 \mathrm{bc}$ & $0.17 \pm 0.05 \mathrm{~b}$ \\
$5 \mathrm{mTR}$ & $13.0 \pm 2.0 \mathrm{a}$ & $10.8 \pm 2.5 \mathrm{a}$ & $2.2 \pm 0.9 \mathrm{bc}$ & $0.20 \pm 0.08 \mathrm{~b}$ \\
\hline
\end{tabular}

${ }^{\mathrm{z}}$ Abnormality index $=$ number of abnormal shoots/number of normal shoots. $\mathrm{n}=15$.

${ }^{\mathrm{y}}$ Mean value and SE $( \pm)$ in the column with different letter(s) are significantly different $(P<0.05)$ by Duncan's multiple range test.
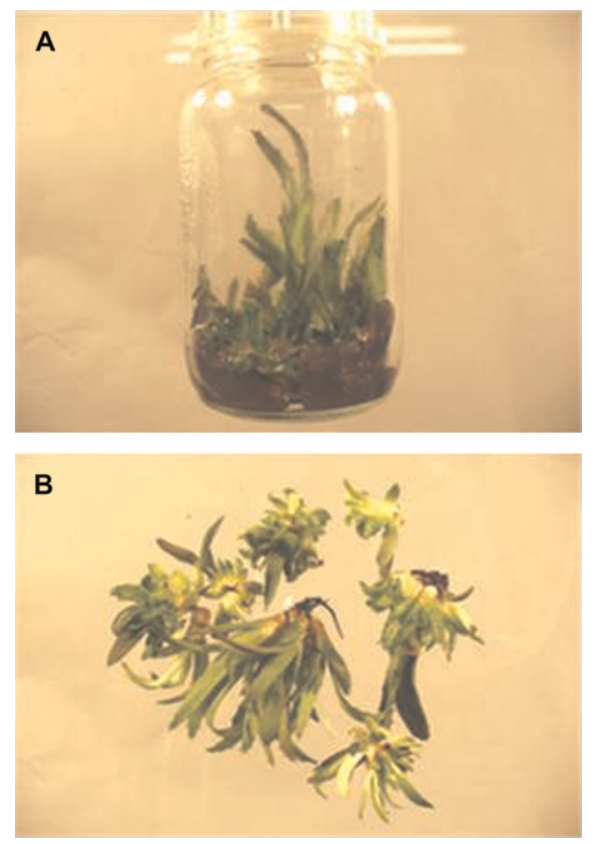

Fig. 6. In vitro shoot multiplication of Aloe ferox: (A) shoot clusters in a jar showing some browning problem; (B) shoot clusters derived from five shoot-tip explants.

effect could partly be attributed to the role minerals play as osmotica. Because any germination process is preceded by imbibition, anything that affects this process is likely to affect germination. There is a report indicating the role sugars play as metabolic regulators of storage proteins during germination. Proteolytic activity was higher in organs cultured on medium without sucrose in germinating seeds of yellow lupine resulting in high intensity of protein reserve activation (Sławomir and Wiktoria, 2002). This could explain the poor shoot induction response observed by seedlings germinated in medium containing sugar.

Shoot induction response increased with a decrease in salt strength of the germination media containing different levels of Murashige and Skoog (1962) salts (Fig. 4). The effect of ions like chloride, sodium, and magnesium on seed germination and plant growth is well documented (Hardegree and Emmerich, 1990). Sodium chloride, for instance, caused a significant delay and inhibition (at higher concentration) on ex vitro germination of Pteroceltis tatarinowii seeds (Sheng-zuo et al., 2006). This could be the result of the effects of salts on water potential, thereby affecting the availability of water to the

Another finding (Table 2) in harmony with our previous reports is the less toxic effect of the topolins compared with BA (Bairu et al., 2007, 2008). This in vitro shoot induction experiment was partly designed to test the applicability of the protocol developed for A. polyphylla in our research center (Bairu et al., 2007) on other Aloe spp. The results of this investigation clearly showed that this protocol can be used for A. ferox. In addition, this and other findings (Bairu et al., 2007; Chukwujekwu et al., 2002) indicate that BA is not a preferred cytokinin in Aloe tissue cultures.

\section{Conclusions}

This study indicates that seeds of A. ferox require a temperature of $21.5{ }^{\circ} \mathrm{C}$ for optimum germination. Treating $A$. ferox seeds with smoke-water $(1: 500 \mathrm{v} / \mathrm{v})$ may help in improving percentage germination. Alternating temperatures $\left(30 / 15{ }^{\circ} \mathrm{C}\right)$ and high irrigation frequencies (three times weekly) would be useful to raise seedlings of $A$. ferox.

In vitro propagation of $A$. ferox was achieved using a previously developed protocol. It should, however, be noted that the germination medium plays a significant role in the shoot induction competence of the seedlings. Seeds germinated in either distilled water or one-tenth strength MS medium gave a superior shoot induction response.

\section{Literature Cited}

Bairu, M.W., W.A. Stirk, K. Doležal, and J. Van Staden. 2007. Optimizing the micropropagation protocol for the endangered Aloe polyphylla: Can meta-topolin and its derivatives serve as replacement for benzyladenine and zeatin? Plant Cell Tissue Organ Cult. 90:1523

Bairu, M.W., W.A. Stirk, K. Doležal, and J. Van Staden. 2008. The role of topolins in micropropagation and somaclonal variation of banana cultivars 'Williams' and 'Grand Naine' (Musa spp. AAA). Plant Cell Tissue Organ Cult. 95:373-379. germinating seed.
Baxter, B.J.M., J. Van Staden, J.E. Granger, and N.A.C. Brown. 1994. Plant-derived smoke and smoke extracts stimulate seed germination of the fire-climax grass Themeda triandra. Environ. Exp. Bot. 34:217-223.

Chukwujekwu, J.C., C.W. Fennell, and J. Van Staden. 2002. Optimisation of the tissue culture protocol for the endangered Aloe polyphylla. S. Afr. J. Bot. 68:424-429.

Donaldson, J. 1989. Criteria for listing on Appendix I and Appendix II. Test of the applicability of the criteria, p. 88-89. In: Munoz, M.C. (comp.). Aloe ferox-Proposed revision of Resolution Conf. 9.24 (CoP12 Com.1.3).

Ellis, R.H. and E.H. Roberts. 1981. The quantification of ageing and survival in orthodox seeds. Seed Sci. Technol. 9:373-409.

Hardegree, S.P. and W.E. Emmerich. 1990. Partitioning water potential and specific salt effects on seed germination of four grasses. Ann. Bot. (Lond.) 66:587-595.

Hoagland, D.R. and W.C. Snyder. 1933. Nutrition of strawberry plants under controlled conditions. Proc. Amer. Soc. Hort. Sci. 30:288296.

International Seed Testing Association. 1999. Biochemical test for viability. Seed Sci. Technol. Supplement 27, $333 \mathrm{p}$.

Knapp, A. 2006. A review of the trade in Aloe ferox with a focus on the role of the European Union. A TRAFFIC Europe report for the European Commission, Brussels, Belgium.

Kulkarni, M.G., S.G. Sparg, M.E. Light, and J. Van Staden. 2006. Stimulation of rice (Oryza sativa L.) seedling vigour by smoke-water and butenolide. J. Agron. Crop Sci. 192:395-398.

Light, M.E. and J. Van Staden. 2004. The potential of smoke in seed technology. S. Afr. J. Bot. 70:97-101.

Maundu, P., P. Kariuki, and O. Eyog-Matig. 2004 Threats to medicinal plant species-An African perspective. Proc. of a global synthesis workshop on Biodiversity and Species Extinctions: Managing Risk in A Changing World. IUCN, World Conservation Congress, Bangkok, 17-25 Nov.

Murashige, T. and F. Skoog. 1962. A revised medium for a rapid growth and bioassays with tobacco tissue cultures. Physiol. Plant. 15:473497.

Newton, D.J. and H. Vaughan. 1996. South Africa's Aloe ferox plant, parts and derivatives industry. TRAFFIC East Southern Africa.

Olff, H., D.M. Pegtel, J.M. Van Groenendael, and J.P. Bakker. 1994. Germination strategies during grassland successions. J. Ecol. 82:69-77.

Pfab, M.F. and M.A. Scholes. 2004. Is the collection of Aloe peglerae from the wild sustainable? An evaluation using stochastic population modelling. Biol. Conserv. 118:695-701.

Rodríguez-García, R., D. Jasso de Rodríguez, J.A. Gil-Marín, J.L. Angulo-Sánchez, and R.H. Lira-Saldivar. 2007. Growth, stomatal resistance transpiration of Aloe vera under different soil water potentials. Ind. Crops Prod. 25:123128.

Sachedina, H. and G. Bodeker. 1999. Wild Aloe harvesting in South Africa. J. Altern. Complement. Med. 5:121-123.

Saks, Y. and N. Ish-shalom-Gordon. 1995. Aloe vera $\mathrm{L}$., a potential crop for cultivation under conditions of low-temperature winter and basalt soils. Ind. Crops Prod. 4:85-90.

Shackleton, C.M. and J. Gambiza. 2007. Growth of Aloe ferox Mill. at selected sites in the Makana region of the Eastern Cape. S. Afr. J. Bot. 73: 266-269. 
Sheng-zuo, F., S. Li-yi, and F. Xiang-xiang. 2006 Effects of $\mathrm{NaCl}$ stress on seed germination, leaf gas exchange and seedling growth of Pteroceltis tatarinowii. J. For. Res. 17:185188.

Sławomir, B. and R. Wiktoria. 2002. Sugars as a metabolic regulator of storage protein mobilization in germinating seeds of yellow lupine
(Lupinus luteus L.). Acta Physiol. Plant. 24:425-434.

Van der Bank, H., B-E. Van Wyk, and M. Van der Bank. 1995. Genetic variation in two economically important Aloe species (Aloaceae). Biochem. Syst. Ecol. 23:251-256.

Van Staden, J., A.K. Jäger, M.E. Light, and B.V. Burger. 2004. Isolation of the major germina- tion cue from plant-derived smoke. S. Afr. J. Bot. 70:654-659.

Van Wyk, B.-E. and G. Smith. 1996. Guide to the Aloes of South Africa. Briza Publications, Pretoria, South Africa.

Van Wyk, B.-E., B. Van Oudtshoorn, and N. Gericke. 1997. Medicinal plants of South Africa. Briza Publications, Pretoria, South Africa. 